Pesq. Vet. Bras. 30(4):340-344, abril 2010

\title{
Evaluation of follicular lymphoid depletion in the Bursa of Fabricius: An alternative methodology using digital image analysis and artificial neural networks ${ }^{1}$
}

\author{
Lucas B. Moraes ${ }^{2}$, Fernando S. Osório ${ }^{3}$, Felipe O. Salle², Guilherme F. Souza², Hamilton \\ L.S. Moraes ${ }^{2}$, Luiz C.B. Fallavena ${ }^{4}$, Luciana R. Santos ${ }^{5}$ and Carlos T.P. Salle ${ }^{2}$
}

\begin{abstract}
Moraes L.B., Osório F.S., Salle F.O., Souza G.F., Moraes H.L.S., Fallavena L.C.B., Nascimento V.P., Santos L.R. \& Salle C.T.P. 2010. Evaluation of follicular lymphoid depletion in the Bursa of Fabricius: An alternative methodology using digital image analysis and artificial neural networks. Pesquisa Veterinária Brasileira 30(4):340-344. Departamento de Medicina Animal, Universidade Federal do Rio Grande do Sul, Avenida Bento Gonçalves 8824, Porto Alegre, RS 91540-000, Brazil. E-mail: lucasbmoraes@gmail.com

Fifty Bursa of Fabricius (BF) were examined by conventional optical microscopy and digital images were acquired and processed using Matlab ${ }^{\circledR} 6.5$ software. The Artificial Neuronal Network (ANN) was generated using Neuroshell ${ }^{\circledR}$ Classifier software and the optical and digital data were compared. The ANN was able to make a comparable classification of digital and optical scores. The use of ANN was able to classify correctly the majority of the follicles, reaching sensibility and specificity of $89 \%$ and $96 \%$, respectively. When the follicles were scored and grouped in a binary fashion the sensibility increased to $90 \%$ and obtained the maximum value for the specificity of $92 \%$. These results demonstrate that the use of digital image analysis and ANN is a useful tool for the pathological classification of the BF lymphoid depletion. In addition it provides objective results that allow measuring the dimension of the error in the diagnosis and classification therefore making comparison between databases feasible.
\end{abstract}

INDEX TERMS: Digital image analysis, Gumboro, bursa of Fabricius, artificial neuronal network.

RESUMO.- [Avaliação da depleção linfóide folicular da Bursa de Fabricius: uma metodologia alternativa utilizando Análise Digital de Imagem e redes neurais artificiais.] Cinquenta Bursa de Fabrícius (BF) foram exa-

\footnotetext{
${ }^{1}$ Received on September 29, 2009.

Accepted for publication on December 3, 2009.

2 Departamento de Medicina Animal, Universidade Federal do Rio Grande do Sul (UFRGS), Av. Bento Gonçalves 8824, Porto Alegre, RS 91540-000, Brazil. *Corresponding author: lucasbmoraes@gmail.com

3. Departamento de Sistemas de Computação, Instituto de Ciências Matemáticas e de Computação, Universidade de São Paulo (USP), Av. Trabalhador São-Carlense 400, Centro, Cx. Postal 668, São Carlos, SP 13560-970, Brazil.

${ }^{4}$ Departamento de Medicina Veterinária, Centro de Ciências da Saúde Campus Canoas, Universidade Luterana do Brasil, Av. Miguel Tostes 101, São Luiz, Canoas, RS 92420-280, Brazil,

${ }^{5}$ Faculdade de Agronomia e Medicina, Universidade de Passo Fundo, Campus I BR 285 Km 17, Cx. Postal 611/631, Passo Fundo, RS 99001-970, Brazil.
}

minadas através de microscopia óptica convencional e imagens digitais foram obtidas e processadas através do software Matlab ${ }^{\circledR}$ 6.5. Redes Neurais Artificiais (ANN) foram geradas com a utilização do software Neuroshell ${ }^{\circledR}$ Classifier, e os dados das análises óptica e digital foram comparados. A ANN classificou corretamente a maioria dos folículos, atingindo sensibilidade e especificidade de $89 \%$ e $96 \%$, respectivamente. Quando os folículos foram agrupados de forma binária houve um aumento da sensibilidade para $90 \%$ e obteve-se um valor máximo para a especificidade de $92 \%$. Estes resultados demonstram que o uso da análise digital de imagem associada à ANN é uma ferramenta bastante útil para a classificação patológica da depleção linfóide da BF. Além disso, fornece resultados objetivos que permitem medir a dimensão do erro classificatório, tornando possível a comparação entre distintos bancos de dados.

TERMOS DE INDEXAÇÃO: Análise digital de imagem, Gumboro, bursa de Fabricius, rede neural artificial. 


\section{INTRODUCTION}

The poultry industry is one of the most advanced areas of the agribusiness, where efficient standards are required to increase quality. Ideal sanitary state of each flock is needed in order to improve genetic potential of the eggs and/or poultry production. However, common immunosuppressive diseases may cause significant losses to the industry itself or increase susceptibility to other diseases.

The main immunosuppressive diseases faced by the industry are: a) Infectious Bursal Disease (IBD; Luckert \& Saif 2003), b) Aflatoxicosis (Hoerr 2003), c) Marek Disease (Witter \& Schat 2003), and d) Infectious Chicken Anemia (Schat 2003). All these conditions cause a marked lymphoid depletion in the BF, spleen, thymus, liver, proventriculum, intestine and kidneys.

Involvement of the BF occurs in all diseases mentioned above and has an important role in the diagnosis as well as in the monitoring of such conditions. Currently, the evaluation of bursal lymphoid depletion depends on a subjective histological evaluation therefore susceptible to errors. In fact, a lesion score has been reported in order to minimize possible subjective errors (Pereira 2002, Moraes et al. 2004, Moraes et al. 2005).

Image Analysis (IA) is a recent tool used in many scientific areas, such as food quality (Li et al. 1999, Lu et al. 2000, Louka et al. 2004, Tan 2004, Faucitano et al. 2005, Fernández et al. 2005, Vestergaard et al. 2005, Yang et al. 2005), agriculture (Santos et al. 1998, Moreira et al. 2004, Throop et al. 2005) and as an aid in disease diagnosis (Novelli et al. 1997, Azevedo-Marques 2001, Babinski et al. 2002, Rosito 2002, Tang et al. 2003). The ANN has been widely used in many scientific areas but presently is under-utilized in the poultry industry and has been scarcely reported in the literature. Salle et al. (2003) proposed its use for breeders management, in the broiler breeders serological results interpretation (Salle et al. 1999), in the management of broiler flocks (Salle et al. 2004), hatchery management (Salle et al. 2006) and as an aid for evaluation of Escherichia coli pathogenicity (Rocha 2006). The ANN was used further to identify the propensity of chickens to develop Pulmonary Hypertension Syndrome (Roush et al., 2001), to evaluate the minimal invasive measurements for early diagnosis of ascites in broilers (Roush et al. 1997), for the detection of septicemia chicken livers (Dey et al. 2003) and to detect wholesome or unwholesome carcasses in on-line inspection (Chao et al. 2002).

In this paper we report the use of IA and ANN techniques to minimize errors that may occur in the conventional optical technology.

\section{MATERIALS AND METHODS}

\section{Bursa of Fabricius samples}

Fifty Bursa of Fabricius (BF) samples were collected intact and kept in individuals vials with $10 \%$ buffered formalin. These organs were collected in the previous experiment realized by Moraes et al. (2004).

\section{Histological examination}

All BF samples were processed for histological examination following the standard technique (Luna 1968) and cut at the level of their major diameter in order to obtain the largest observation area.

The slides were first evaluated throughout the conventional subjective method (optical), and the degree of lymphoid depletion scored in a scale from 1 to 5 : Score $1=<25 \%$ depletion; Score $2=25$ to $50 \%$ depletion; Score $3=50$ to $75 \%$ depletion; Score $4=75$ to $90 \%$ depletion; and Score $5=>90 \%$ depletion (Muskett et al. 1979). The samples were scored 3 times by a single examiner with an interval of one day between examinations.

\section{Image capture}

Ten slides of each score were randomly selected for image processing. Each slide was divided in 4 parts and three follicles for each quadrant were selected for examination. The quadrants were numbered clock-wise (I to IV) and the follicles in crescent order (1 to 12; Fig.1).

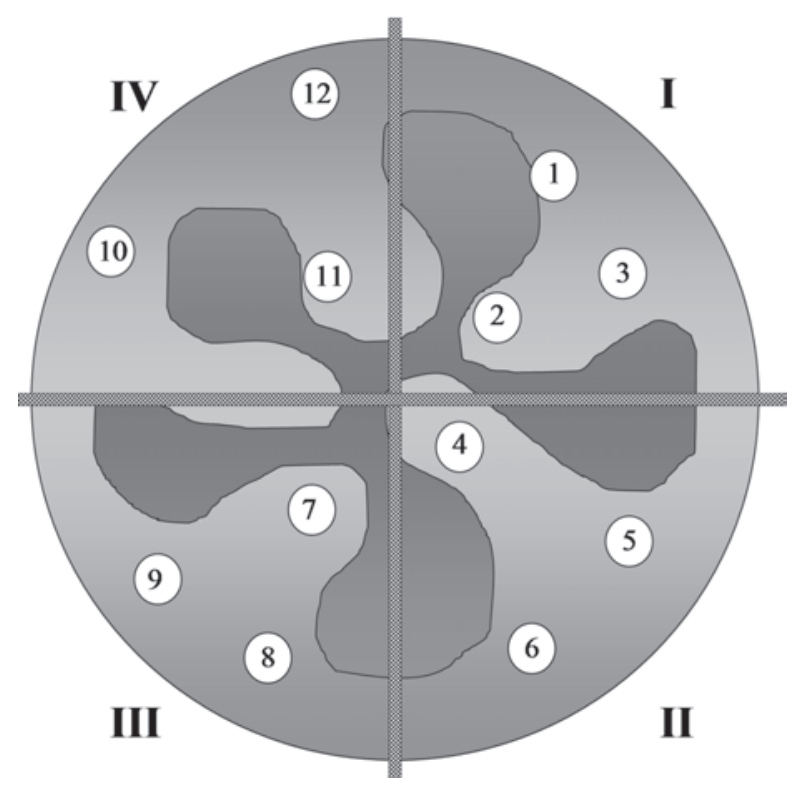

Fig.1. Slide divided into quadrants numbered clock-wise (I to IV) and three follicles for each quadrant numbered in crescent order (1 to 12).

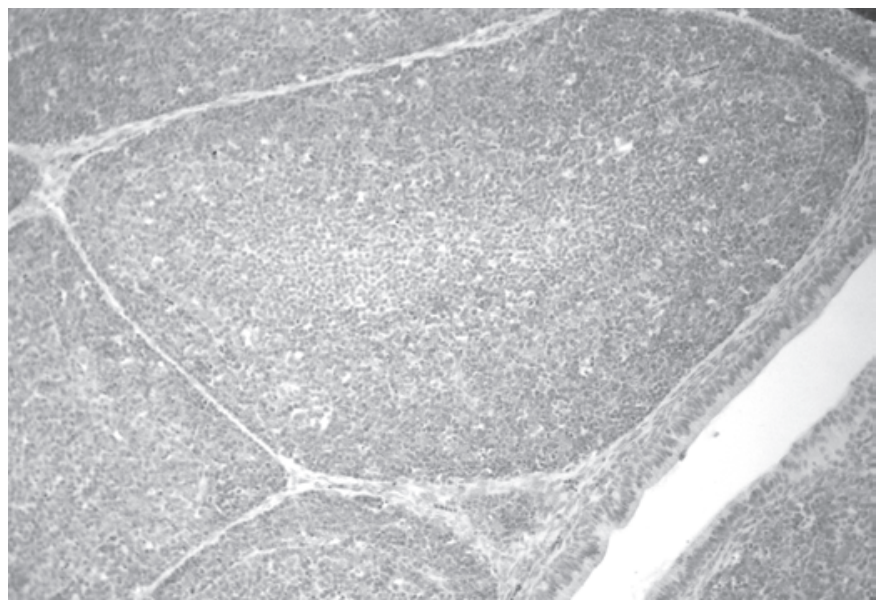

Fig.2. The target follicle image in gray scale. 
Finally digital photomicrographic images were taken under a 20X magnification with an Olympus ${ }^{\circledR}$ C-7070 camera (Fig.2).

\section{Image analysis}

The images were assayed using a Matlab ${ }^{\circledR} 6.5$ software according to the following steps: a) change to gray scale (Fig.2); b) select the follicular area immediately close to the inter-follicular conjunctive tissue; c) all structures around the selected area were rubbed out and the number of pixels for gray scale of each image was estimated (Fig.3); and (d) the image histograms and table were constructed (Fig.4).

Areas of the histogram were selected and their corresponding

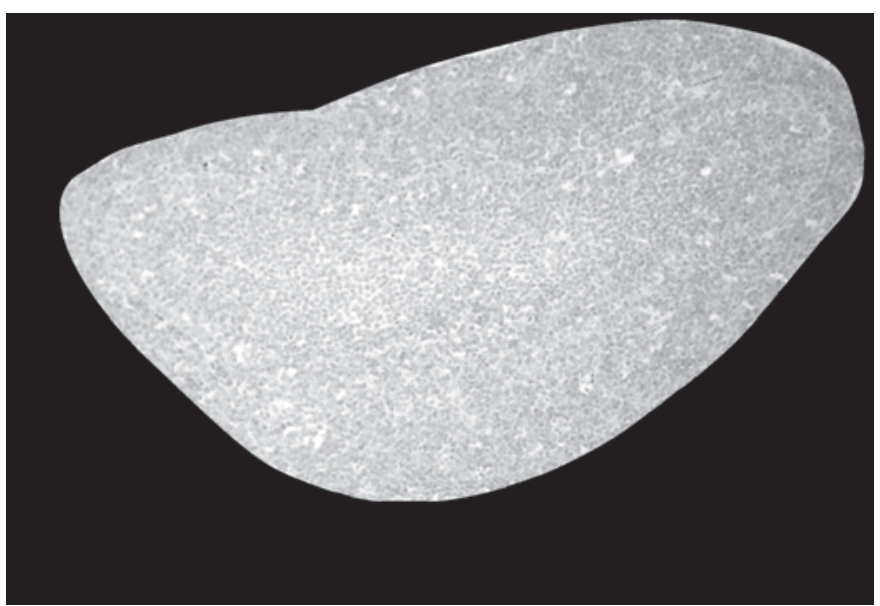

Fig.3. The follicular area was selected and others parts around of it were deleted.

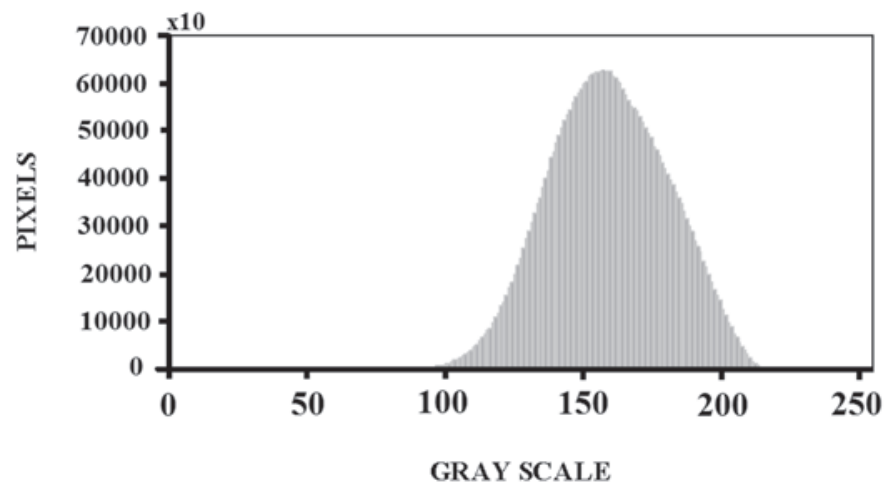

Fig.4. The image histogram where the data were obtained.

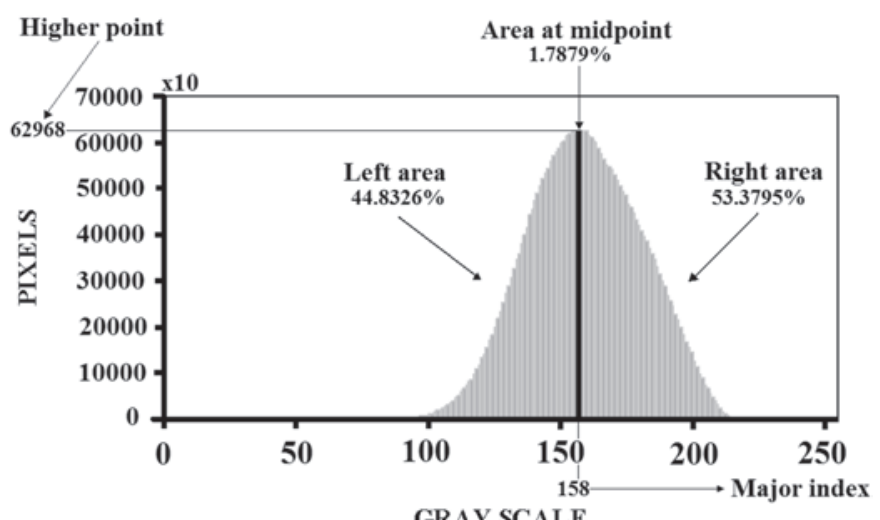

Fig.5. Example of histogram data selected for ANN input. data (right and left area, area at the mid-point, midpoint values at $\mathrm{X}$ (major index) and $\mathrm{Y}$ (higher point) provide the input to construct the Artificial Neuronal Network (ANN; Fig.5). Identification and digital classification of the follicles with different lymphoid depletion scores was performed using the Neuroshell ${ }^{\circledR}$ Classifier, 2.1, Ward Systems Group, Inc. software. This data was used to train the ANN to obtain a digital score which is compared with the score obtained by optical classification. This procedure is performed for each selected follicle.

\section{RESULTS}

The ANN was able to make a comparable classification of digital and optical scores. High sensibility and specificity was found in scores 1 where only nine follicles were misclassified as score 2. It was more difficult to find agreement between ANN and optical classification in more severe cases of depletion and both sensibility and specificity decreased in scores 3,4 and 5 (Table 1).

In attempt to improve accuracy of the ANN, scores 1 and 2, 4 and 5, were agglutinated and named $1 \mathrm{~A}$ and $5 \mathrm{~A}$, respectively. Score 3 was maintained intact. In spite of this change the ANN performance remained similar to previous classification, having a area of difficult classification in score 3 where 31 follicles were misclassified as $5 \mathrm{~A}$ (Table 2). It is important to point out that the ANN classification changes with regrouping the scores reason why the numbers in Table 2 are different than in Table 1, even though the input values are unchanged. The regrouping obliges the ANN to retrain in a new model, reason why the values for $1 \mathrm{~A}$ and $1 \mathrm{~B}$ are different despite having unchanged optical and digital findings.

Aiming to improve accuracy of the ANN the follicles were then grouped in a binary fashion, separating the

Table 1. Relationship between classification of follicles using Digital Scores and conventional Optical Scores

\begin{tabular}{ccccccc}
\hline Scores & OS1 & OS 2 & OS 3 & OS 4 & OS 5 & Total \\
\hline DS1 & 97 & 26 & 19 & 1 & 3 & 146 \\
DS2 & 9 & $\mathbf{6 7}$ & 5 & 0 & 4 & 85 \\
DS3 & 1 & 10 & $\mathbf{5 3}$ & 20 & 34 & 118 \\
DS4 & 0 & 0 & 11 & $\mathbf{8 4}$ & 17 & 112 \\
DS5 & 1 & 17 & 32 & 15 & $\mathbf{6 2}$ & 127 \\
Total & 108 & 120 & 120 & 120 & 120 & 588 \\
Sensibility (\%) & 89.81 & 55.83 & 44.17 & 70.00 & 51.67 & \\
Specificity (\%) & 89.79 & 96.17 & 86.11 & 94.02 & 88.11 &
\end{tabular}

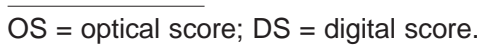

Table 2. Follicles classification in three Digital Scores and the Optical Scores obtained by the conventional method

\begin{tabular}{ccccc}
\hline & OS1A & OS3 & OS5A & Total \\
\hline DS1A & 181 & 14 & 15 & 210 \\
DS3 & 29 & 75 & 68 & 172 \\
DS5A & 18 & 31 & 157 & 206 \\
Total & 228 & 120 & 240 & 588 \\
Sensibility (\%) & 79.39 & 62.5 & 65.42 & \\
Specificity (\%) & 91.94 & 79.27 & 85.92 & \\
\hline
\end{tabular}

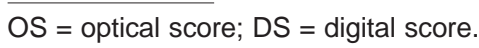


Table 3. Follicles classification in two scores using Digital Score and the Optical Scores obtained by the conventional method

\begin{tabular}{cccc}
\hline & OS1B & OS5B & Total \\
\hline DS1B & $\mathbf{2 1 1}$ & 35 & 246 \\
DS5B & 17 & $\mathbf{3 2 5}$ & 342 \\
Total & 228 & 360 & 588 \\
Sensibility (\%) & 92.54 & 90.28 & \\
Specificity (\%) & 90.28 & 92.54 & \\
\hline
\end{tabular}

OS = optical score; $\mathrm{DS}=$ digital score

scores of the BF in normal and clearly abnormal. Scores 1 and 2, and scores 3, 4 and 5 were agglutinated in score $1 \mathrm{~B}$ and $5 \mathrm{~B}$, respectively. With this alternative the accuracy of the ANN improved significantly with sensibility and specificity higher than $90 \%$ (Table 3 ). Again, as noted above, the values change with regrouping in Table 3 because the ANN retrains in a binary fashion.

\section{DISCUSSION}

The results of this study suggest that the digital image analysis using the Matlab ${ }^{\circledR} 6.5$ combined with the ANN is a helpful tool in the diagnosis of follicular lymphoid depletion in BF. One advantage of this new methodology is that it does not need special histological techniques, since it can be performed with routine $\mathrm{H}$-E staining. In addition it does not require a sophisticated training to implement the referred protocol. The use of digital imaging reduces the subjectivity of the conventional optical technique and potentially improves the depletion accuracy.

The use of ANN showed to be efficient for all digital score lesions with less accuracy in scores 2, 3 and 4. This inconsistency maybe due to the fact that the images for these scores could have similar appearance on routine optical evaluation and is encountered even when experienced pathologists perform their histological assessment.

The optical score 1 and 2 are similar histologically, and often pose difficulties for the pathologist to allocate in one or in the other score. The same difficulty is encountered when ANN methodology is used, but with the advantaged that the "error" (sensibility and specificity) is informed by the software. This difficulty is also seen for the follicles with optical score 3 , since only 53 samples $(44.17 \%)$ were correctly evaluated and 43 (35.83\%) were allocated on scores 4 and 5 . A similar confounding area is also detected for the optical scores 4 and 5 .

The ANN performance improves with grouping of the scores. When the scores are grouped in a binary fashion, simulating a more realistic situation where the animal is either healthy or sick, the ANN accuracy increases significantly. This is reinforced by Pereira (2002) and Moraes et al. (2004) who suggest that a bird should be considered sick only when BF using optical score is 3 or more. Therefore regrouping the scores in a binary fashion for ANN training does make sense.

The use of ANN to determine the pathogenicity index (PI) for Escherichia coli has been recently reported by
Rocha (2006). The author classified the PI in 10 categories and found a variable sensibility but a high specificity (above $95 \%$ ). Similar to our study, the variability in sensibility was attributed to the number of the PI categories. When the PI was classified in three categories: non virulent, of intermediary pathogenicity and virulent the ANN gave more reliable results.

The results found in this study suggest that the use of digital image analysis and ANN is a helpful tool for routine laboratorial evaluation of BF histological lesions. The use of ANN allows a more accurate and reliable reading of the histological lymphoid depletion, independent of the operator or laboratory where it is carried out. As the ANN constructs an objective scale the results can be compared from different laboratories and therefore is advantageous when compared to the conventional subjective methodology. For instance, poultry companies with subsidiaries in distinct geographic areas could exchange data related to monitoring programs and elaborate a realistic risk analysis for BF lymphoid depletion.

Finally, it must be emphasized that although the use of ANN enhances the ability to evaluate BF lymphoid depletion, the presence of a trained pathologist is essential for the differential diagnosis of other conditions.

Acknowledgements.- To Dr. Luiz Alberto Oliveira Ribeiro and Dr. João Luiz Pippi Salle for all their help editing this manuscript construction.

\section{REFERENCES}

Azevedo-Marques P.M. 2001. Diagnóstico auxiliado por computador na radiologia. Rad. Bras. 34(5):285-293.

Babinski M.A., Chagas M.A., Costa W.S. \& Pereira J.M. 2002. Morphology and areal fraction of the glandular lumen of transition zone in the human prostate. Revta Chilena de Anatomia 20(3):255267.

Chao K., Chen Y.R., Hruschka W.R. \& Gwozdz F.B. 2002. On-line inspection of poultry carcasses by dual-camera system. J. Food Engineering 51:185-192.

Dey B.P., Chen Y.R., Hsief C. \& Chan D.E. 2003. Detection of septicemia in chicken livers by spectroscopy. Poultry Sci. 82:199-206.

Faucitano L., Huff P., Teucher F., Gariepy C. \& Wegner J. 2005. Application of computer image analysis to measure pork marbling characteristics. Meat Sci. 69:537-543

Fernández L., Castillero C. \& Aguilera J.M. 2005. An application of image analysis to dehydration of apple discs. J. Food Engineering 67:185193.

Hoerr F.J. 2003. Mycotoxicoses, p.1103-1132. In: Calnek B.W. (Ed.), Diseases of Poultry. lowa State University Press, Ames.

Li J., Tan J., Martz F.A. \& Heymann H. 1999. Image texture features as indicators of beef tenderness. Meat Sci. 53:17-22.

Louka N., Juhel F., Fazilleau V. \& Loonis P. 2004. A novel colorimetric analysis used to compare different drying fish processes. Food Control 15:327-334.

Lu J., Tan J., Shatadal P. \& Gerrard D.E. 2000. Evaluation of pork color by using computer vision. Meat Sci. 56:57-60.

Luckert P.D. \& Saif Y.M. 2003. Infectious Bursal Disease, p.161-179. In: Calnek B.W. (Ed.), Diseases of Poultry. lowa State University Press, Ames.

Luna L.G. 1968. Manual of Histologic Staining Methods of the Armed Forces Institute of Pathology. $13^{\text {th }}$ ed. McGraw-Hill, New York. 258p. 
Moraes H.L.S., Salle C.T.P., Nascimento V.P., Salle F.O., Rocha A.C.G. P., Souza G.F., Furian T.Q. \& Artencio J.O. 2005. Infectious Bursal Disease: Evaluation of maternal immunity and protection by vaccination of one-day old chicks against challenge with a very virulent virus isolate. Braz. J. Poultry Sci. 7(1):51-57.

Moraes H.L.S., Salle C.T.P., Padilha A.P., Nascimento V.P., Souza G.F., Pereira R.A., Artencio J.O. \& Salle F.O. 2004. Infectious Bursal Disease: Evaluation of pathogenicity of commercial vaccines from Brazil in specific-pathogen-free chickens. Braz. J. Poultry Sci. 6(4):243247.

Moreira M.A., Adami M. \& Rudorff B.F.T. 2004. Análise espectral e temporal da cultura de café em imagens Landsat. Pesq. Agropec. Bras. 39(3):223-231.

Muskett J.C., Hopkins I.G., Edwards K.R. \& Thornton D.H. 1979. Comparison of two infectious bursal disease vaccine strains: Efficacy and potential hazards in susceptible and maternally immune birds. Vet. Rec. 104:332-334.

Novelli M.D., Barreto E., Matos D., Saad S.S. \& Borra R.C. 1997. Aplicação de processamento de imagens por computador na quantificação das variáveis histológicas da reparação tecidual de anastomoses colocólicas em cães. Revta Assoc. Méd. Brasil 43(4):277-282.

Pereira R.A. 2002. Relação entre a população linfocitária bursal e diâmetro de bolsa de Fabrício em frangos de corte. MSc. Dissertação, Universidade Federal do Rio Grande do Sul, Porto Alegre, RS.

Rocha A.C.G.P. 2006. Utilização de Inteligência artificial (redes neurais artificiais) para classificação de patogenicidade de amostras de Escherichia coli isoladas de frangos de corte. Tese de Doutorado, Universidade Federal do Rio Grande do Sul, Porto Alegre, RS.

Rosito M.A. 2002. Caracterização de núcleos celulares no adenocarcinoma primário de reto por análise de imagem digital. Tese de Doutorado em Medicina (Cirurgia), Faculdade de Medicina, Universidade Federal do Rio Grande do Sul, Porto Alegre.

Roush W.B., Cravener T.L., Kirby Y.K. \& Wideman R.F. 1997. Probabilistic Neural Network prediction of ascites in broilers based on minimal invasive physiological factors. Poultry Sci. 76:1513-1516.

Roush W.B., Wideman R.F., Cahaner A. Jr, Deeb N. \& Cravener T.L. 2001. Minimal number of chicken daily growth velocities for Artificial Neural Networks (ANN) detection of Pulmonary Hypertension Syndrome (PHS). Poultry Sci. 80:254-259.
Salle C.T.P., Cé M., Wald V.B., Santos C.H.C., Nascimento V.P., Canal C.W., Moraes H.L.S. \& Oliveira S.D. 1999. Estabelecimento de critérios de interpretação para resultados sorológicos de matrizes de corte através de modelos matemáicos. Braz. J. Poultry Sci. 1(1):61-65.

Salle C.T.P., Guahyba A.S., Wald V.B., Silva A.B., Salle F.O. \& Nascimento V.P. 2003. Use of artificial neural networks to estimate production variables of broiler breeders in the production phase. Brit. Poultry Sci. 44(2):211-217.

Salle C.T.P., Reali E.H., Guahyba A.S., Salle F.O., Rocha A.C.G.P. \& Moraes H.L.S. 2004. Utilização de inteligência artificial (redes neurais artificiais) no gerenciamento da produção de frangos de corte. Apinco Conference of Poultry Science and Technology, Santos, Brazil, p.158.

Salle F.O., Pinto P.R., Martins S.S., Moraes H.L.S., Nascimento V.P. \& Salle C.T.P. 2006. Utilização de inteligência artificial (redes neurais artificiais) no gerenciamento do incubatório de uma empresa avícola do sul do Brasil. Apinco Conference of Poultry Science and Technology, Santos, Brazil, p.170.

Santos J.R., Lacruz M.S.P., Keil M., Kux H.J.H. \& Xaud M.R. 1998. Análise de imagem JERS-1 para estimativa de biomassa aérea de florestas tropicais no sudoeste da Amazônia. Proc. IX Simpósio Brasileiro de Sensoriamento Remoto, Santos, Brasil, p.11-18.

Schat K.A. 2003. Chicken Infectious Anemia, p.182-202. In: Calnek B.W. (Ed.), Diseases of Poultry. lowa State University Press, Ames.

Tan J. 2004. Meat quality evaluation by computer vision. J. Food Engineering 61:27-35.

Tang H.L., Hanka R. \& Horase H.S. 2003. Histological image retrieval based on semantic content analysis. IEEE Transactions on Information Technology in Biomedicine 7(1).

Throop J.A., Aneshansley D.J., Anger W.C. \& Peterson D.L. 2005. Quality evaluation of apples based of surface defects: Development of an automated inspection system. Postharvest Biol. Technol. 36:281-290.

Vestergaard C., Erbou S.G., Thauland T., Adler-Nissen J. \& Berg P. 2005. Salt distribution in dry-cured ham measure by computed tomography an image analysis. Meat Sci. 69:9-15.

Yang C., Chao K. \& Chen Y. 2005. Development of multispectral image processing algorithms for identification of wholesome, septicemic, and inflammatory process chickens. J. Food Engineering 69:225-234.

Witter R.L. \& Schat K.A. 2003. Marek's disease, p.407-465. In: Calnek B.W. (Ed.), Diseases of Poultry. lowa State University Press, Ames. 